\title{
SISTEM PAKAR DIAGNOSA PENYAKIT KISTA OVARIUM DENGAN METODE FORWARD CHAINING
}

\author{
Aggy Pramana Gusman, Dian Maulida, Eva Rianti \\ Universitas Putra Indonesia "YPTK" Padang, Indonesia \\ e-mail: apgusman@gmail.com, dianmaulida07@gmail.com, evarianti@gmail.com
}

\begin{abstract}
ABSTRAK
Penyakit Kista Ovarium umumnya hanya dapat menyerang kaum wanita setelah berumur 25 tahun keatas kurangnya pengetahuan masyarakat mengenai gejala-gejala dari penyakit kista ovarium inilah yang menjadi masalahnya maka dari itu disini penulis membuat sistem pakar diagnosa penyakit Kista Ovarium dengan Metode Forward Chaining yaitu dimana pasien melakukan konsultasi dengan cara menjawab beberapa pertanyaan yang berkaitan dengan gejala Kista Ovarium dan pasien menjawab pertanyaan sesuai dengan gejala yang dirasakan oleh pasien. Sistem pakar ini dibuat dengan menggunakan Bahasa Pemrograman PHP dan Database Mysql. Diharapkan dengan adanya sistem pakar diagosa penyakit Kista Ovarium ini nantinya dapat memudahkan pasien dalam berkonsultasi mengenai penyakit Kista Ovarium ini dan dapat menambah pengetahuan bagi sipasien.
\end{abstract}

Kata Kunci: Kista Ovarium, Sistem Pakar, Forward Chaining.

\begin{abstract}
Ovarian cyst disease can only attack women after 25 years old of age and above the lack of public knowledge about the symptoms of ovarian cyst disease is the problem, therefore the authors make an expert system diagnosing ovarian cyst disease with a forward chaining method where patients consults with how to answer a number of questions related to the symptoms of an ovarian cyst and the patients answers questions according to the symptoms felt by the patient. This expert system is created using the PHP programming language and MYSQL database. It is expected that with an expert system of diagnosing ovarian cyst disease, later it can facilitate patients in consulting about his ovarian cyst disease and can increase knowledge for the patient.
\end{abstract}

Keywords: Ovarium Csyt, Expert System, Forward Chaining.

\section{Pendahuluan}

Sistem pakar (Expert System) secara umum adalah sistem yang berusaha mengadopsi pengetahuan manusia ke komputer, agar komputer dapat bertindak menyelesaikan masalah seperti yang biasa dilakukan oleh para ahli Menurut sukama hendra.[1] Penyakit Kista Ovarium adalah jenis penyakit yang hanya dialami oleh wanita saja. Dimana penyakit Kista Ovarium ini adalah penyakit yang menyerang bagian indung telur yang dimiliki seorang wanita saja.Bagi masyarakat, penyakit Kista Ovarium masih banyak yang belum mengetahui tentang penyakit tersebut. Baik tentang penyebab, gejala serta cara pencegahan penyakit tersebut. Oleh karena itu penulis ingin membantu permasalahan yang ada dengan pembuatan sistem pakar yang dapat mendiagnosa penyakit Kista Ovarium. Pada penelitian ini akan diterapkan suatu metode yang dapat menentukan penyakit berdasarkan gejala-gejalanya yaitu Metode Forward Chaining. Metode Forward Chaining adalah teknik pencarian yang dimulai dengan fakta yang diketahui, kemudian mencocokan fakta-fakta tersebut dengan bagian IF dari rules IF-THEN. Oleh karena itu diperlukan suatu sistem yang lebih praktis dan memiliki kemampuan layaknya seorang ahli (pakar) dalam mendiagnosa penyakit Kista Ovarium. Sistem tersebut adalah suatu sistem yang dapat memberikan solusi kepada para pengguna layaknya seperti yang dilakukan oleh seorang pakar.

\section{TinjauAn Literatur}

\subsection{Pengertian Sistem Pakar}

Menurut Anik Andriani (2017:9) Sistem pakar adalah sebuah sistem yang kinerjanya mengadopsi keahlian yang dimiliki seorang pakar dalam bidang tertentu kedalam sistem atau program komputer yang disajikan dengan tampilan yang dapat digunakan oleh pengguna yang bukan seorang pakar 
sehingga dengan sistem tersebut pengguna dapat membuat sebuah keputusan atau menentukan kebijakan layaknya seorang pakar. [2]

\subsection{Keuntungan dan Kelemahan Sistem Pakar}

Penggunaan sistem pakar secara umum memberikan keuntungan yang dapat dimanfaatkan langsung oleh pengguna. Adapun keuntungan dari penggunaan sistem pakar antara lain [3]:

1. Memungkinkan pengguna yang bukan seorang pakar pada bidang tertentu dapat mengerjakan tugas dari seorang pakar.

2. Bisa melakukan proses yang sama secara berulang.

3. Sistem pakar dapat menyimpan pengetahuan dan keahlian dari pakar.

4. Dengan adanya sistem pakar produktivitas dan output sistem dapat ditingkatkan

5. Meningkatkan kualitas.

6. Mampu mengambil dan melestarikan keahlian para pakar.

7. Mampu beroperasi dalam lingkungan yang berbahaya.

8. Memiliki kemampuan untuk mengakses pengetahuan.

9. Memiliki reabilitas.

10. Meningkatkan kapabilitas sistem komputer.

11. Memiliki kemampuan untuk bekerja dengan informasi yang tidak lengkap dan mengandung ketidakpastian.

12. Sebagai media pelengkap dalam pelatihan.

13. Meningkatkan kapabilitas dalam penyelesaian masalah.

14. Menghemat waktu dalam pengambilan keputusan.

Sistem pakar juga mempunyai kelemahan selain banyaknya keuntungan yang diberikan, antara lain:

1. Biaya yang diperlukan untuk membuat, memelihar, dan mengembangkan sistem pakar sangat mahal.

2. Sulit dikembangkan, karena ketersediaan pakar dibidangnya dan kepakaran sulit diekstrak dari manusia karena terkadang sulit bagi seorang pakar untuk menjelaskan langkah mereka dalam menangani masalah.

3. Sistem pakar tidak $100 \%$ benar karena seseorang yang terlibat dalam pembuatan sistem pakar tidak selalu benar. Oleh karena itu setelah pembuatan sistem pakar harus dilakukan pengujian terlebih dahulu secara teliti sebelum digunakan.

4. Pendekatan oleh setiap pakar untuk suatu situasi atau problem bisa berbeda-beda, meskipun sama-sama benar.

5. Transfer pengetahuan dapat bersifat subjektif dan bias.

6. Kurangnya rasa percaya pengguna dapat menghalangi pemakaian sistem pakar.

\subsection{Struktur Sistem Pakar}

Dalam jurnalnya Komponen utama pada struktur sistem pakar meliputi:[4]

1. Akuisisi pengetahuan

Subsistem ini di gunakan untuk memasukan pengetahuan dari seorang pakar dengan cara merekayasa pengetahuan agar bisa di proses oleh komputer dan menaruhnya dalam basis pengetahuan dalam format tertentu ( dalam bentuk representasi pengetahuan )

2. Basis pengetahuan ( knowledge base )[5].

Basis pengetahuan mengandung pengetahuan yang di perlukan untuk memahami, menformulasikan, dan menyelesaikan masalah. Basis pengetahuan terdiri dari dua elemen dasar yaitu :

a. Fakta, misalnya situasi kondisi dan permasalahan yang ada

b. Rule ( aturan ) untuk mengarahkan pengunaan pengetahuan dalam memeca kan masalah 
3. Mesin inferensi[6].

Mesin inferensi adalah sebuah program yang berfungsi untuk memandu proses penalaran terhadap suatu kondisi berdsarkan pada basis pengetahuan yang ada, memanipulasi dan mengarahkan kaidah, model dan fakta yang di simpan dalam basis pengetahuan untuk mencapai solusi dan kesimpulan.

4. Daerah kerja ( blackboard )[7].

Untuk merekam hasil sementara yang akan di jadikan sebagai keputusan dan untuk menjelaskan suatu masalah yang sedang terjadi, sistem pakar membutuhkan balckboard, yaitu area pada memori sebagai basis data. Tiga tipe keputusan yang dapat di rekam pada balckboard yaitu :[8]

a. Rencana : bagaimana menghadapi masalah

b. Agenda : aksi - aksi potensial yang menunggu untuk di eksekusi

c. Solusi : calon aksi yang akan di bangkitkan

5. Antarmuka pengguna

Di gunakan sebagai media komunikasi antar pengguna dan sistem pakar.

6. Subsistem penjelasan

Berfungsi memberi penjelasan kepada pengguna bagaimana suatu kesimpulan dapat di ambil.

7. Sistem perbaikan pengetahuan

Kemampauan memperbaiki pengetahuan (knowledge refining system ) dari seorang pakar di perlukan untuk menganalisa pengetahuan, belajar dari kesalahan masa lalu, kemudian memperbaiki pengetahuannya sehingga dapat di pakai di masa akan datang.

8. Pengguna

Pada umumnya pengguna sistem pakar bukanlah seorang pakar ( non expert ) yang membutuhkan solusi, saran, atau pelatihan ( training ) dari berbagai permasalahan yang ada [5].

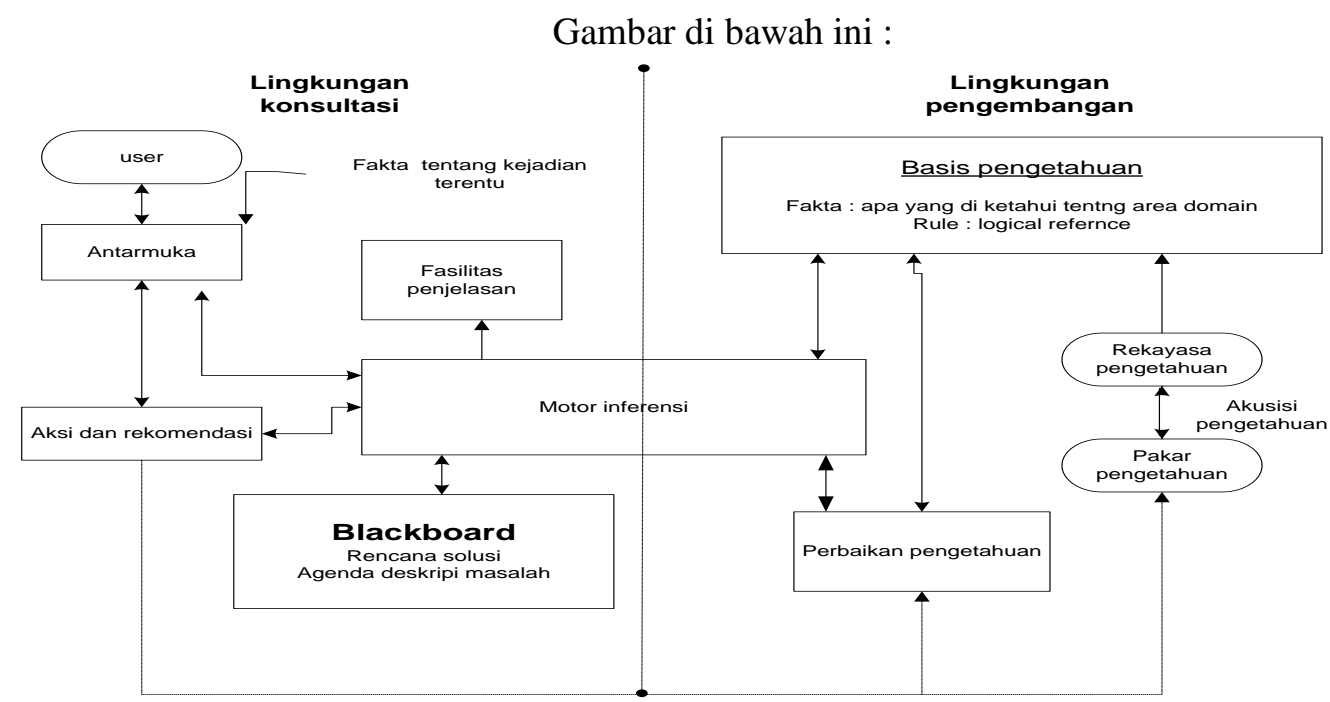

Sumber : (Jurnal Pendidikan Dan Teknologi Vo.2, No.1, September 2015 ISSN: 2355-9977)

Gambar 2.1 Hubungan Antar Komponen Sistem Pakar

\section{Analisa Dan Perancangan}

\subsubsection{Data Penyakit}


Masalah yang dibahas dalam penelitian ini adalah mengenai penyakit kista ovarium. Setelah melakukan wawancara dengan pakar, sehingga mendapatkan kejelasan tentang penyakit kista ovarium tersebut. Adapun macam penyakit dari kista ovarium ini dapat dilihat pada Tabel 3.1.

Tabel 3.1. Macam Penyakit

\begin{tabular}{llcc}
\hline $\mathbf{N}$ & Kode & Nama & Keterangan \\
O & Penyakit & Penyakit &
\end{tabular}

\begin{tabular}{|c|c|c|}
\hline 1. $\mathrm{P} 001$ & $\begin{array}{l}\text { Kistadenoma Ovarii } \\
\text { Serosum }\end{array}$ & $\begin{array}{l}\text { Kista ini berasal dari epitel } \\
\text { germinativum. Bentuk kista umumnya } \\
\text { Unilokular tapi jika multilokular perlu } \\
\text { dicurigai adanya keganasan. Kista ini } \\
\text { dapat membesar, tetapi tidak sebesar } \\
\text { kista musinosum. Selain teraba massa } \\
\text { intraabdominal juga dapat timbul asites. } \\
\text { Penatalaksanaan umumnya sama dengan } \\
\text { kista denoma ovarii musinosum }\end{array}$ \\
\hline 2. $\mathrm{P} 002$ & $\begin{array}{l}\text { Kistadenoma Ovarii } \\
\text { Musinosum }\end{array}$ & $\begin{array}{l}\text { Bentuk kista multilokular dan biasanya } \\
\text { unilateral, dapat tumbuh menjadi sangat } \\
\text { besar. Gambaran klinis terdapat } \\
\text { perdarahan dalam kista dan perubahan } \\
\text { degeneratif sehingga timbul perleketan } \\
\text { kista denganomentum, usus-usus, dan } \\
\text { peritoneum parietale. Selain itu, bisa } \\
\text { terjadi ileus karena perleketan dan } \\
\text { produksi musin yang terus bertambah } \\
\text { akibat pseudomiksoma peritonei. } \\
\text { Penatalaksanaan dengan pengangkatan } \\
\text { kista in tito tanpa pungsi terlebih dulu } \\
\text { dengan atau tanpa salpingo ooforektomi } \\
\text { tergantung besarnya kista. }\end{array}$ \\
\hline 3. $\mathrm{P} 003$ & Kista Dermoid & $\begin{array}{l}\text { Kista Dermoid ialah satu terotoma kistik } \\
\text { yang jinak dimana stuktur-stuktur } \\
\text { ektodermal dengan diferensiasi } \\
\text { sempurna, seperti epital kulit, rambut, } \\
\text { gigi dan produk glandula sebasea } \\
\text { berwarna putih kuning menyerupai } \\
\text { lemak nampak lebih menonjol dari pada } \\
\text { elemen-elemen entoderm dan mesoderm. } \\
\text { Tidak ada ciri-ciri yang khas pada Kista } \\
\text { Dermoid. Dinding kista kelihatan putih, } \\
\text { keabu-abuan, dan agak tipis. Konsistensi } \\
\text { tumor sebagian kistik kenyal, dan } \\
\text { dibagian lain padat. }\end{array}$ \\
\hline
\end{tabular}


bagian endometrium yang berada di luar rahim. Kista ini berkembang bersamaan dengan tumbuhnya lapisan endometrium setiap bulan sehingga menimbulkan nyeri hebat, terutama saat menstruasi dan infertilitas.

\subsubsection{Data Gejala Penyakit}

Adapun gejala-gejala dari penyakit Kista Ovarium ini dapat dilihat pada Tabel 3.2.

Tabel 3.2. Gejala-gejala penyakit

\begin{tabular}{|c|c|c|}
\hline No & Kode Gejala & Nama Gejala \\
\hline 1. & G001 & Adanya Ketidak Teraturan Menstruasi \\
\hline & G002 & Nyeri Pada Perut Bagian Bawah \\
\hline 3. & G003 & Perut Berasa Penuh \\
\hline 4. & G004 & Adanya Timbul Benjolan Pada Perut \\
\hline 5. & G005 & Nyeri Parah Saat Menstruasi \\
\hline 6. & G006 & Berat Badan Menurun \\
\hline & G007 & Tidak Sanggup Mencerna \\
\hline & G008 & Menstruasi Yang Datang Terlambat \\
\hline & G009 & Rasa Nyeri Perut Dapat Muncul Tiba-Tiba \\
\hline & G010 & Sering Kali Merasakan Nyeri Pungggung Bawah \\
\hline & G011 & Tubuh Merasa Lemas \\
\hline & G012 & Sering Muntah-Muntah \\
\hline & G013 & Nyeri Saat Berhubungan Seksual \\
\hline & G014 & $\begin{array}{l}\text { Ganguan Buang Air Besar Atau Kecil Adanya Darah } \\
\text { Pada Urine Atau Tinja }\end{array}$ \\
\hline & G015 & Pendarahan Menstruasi Berlebihan \\
\hline & G016 & Sulit Punya Anak Dalam Kurun Waktu 1 Tahun \\
\hline
\end{tabular}

\subsection{Analisa Proses}

Dalam mengembangkan sistem pakar ini pengetahuan dan informasi diperoleh dari beberapa sumber, yaitu dari dokter, serta dari buku tentang penyakit Kista Ovarium. Pengetahuan ini akan direpresentasikan dalam bentuk rule yang berguna untuk menemukan kesimpulan terhadap penyakit Kista Ovarium dan solusinya[9]. Pada dasarnya rule terdiri dari dua bagian pokok, yaitu bagian premise atau kondisi dan bagian conclution atau kesimpulan. Struktur rule secara logika menghubungkan satu atau lebih kondisi (premise) pada bagian IF (yang akan menguji kebenaran dari serangkaian data) dengan satu atau lebih kesimpulan (conclusion) yang terdapat pada bagian THEN[10].

Selain rule, pada sistem pakar juga dibutuhkan database yang berisi fakta tentang penyakit kista ovarium. Dengan adanya rule dan database ini belum cukup untuk menyelesaikan penyakit Kista Ovarium, untuk menelusuri masalah dibutuhkan sebuah Mesin Inferensi. Metode Inferensi yang digunakan dalam penelusuran masalah pada sistem pakar Jurnal KomtekInfo Vol : 6 No : $1 \| 2019$ 
diagnosa penyakit Kista Ovarium adalah Forward Chaining (penelusuran maju), metode ini adalah teknik pencarian yang dimulai dengan fakta yang diketahui, kemudian mencocokan fakta-fakta tersebut dengan bagian IF dari rules IF-THEN [11].

\subsubsection{Proses Rule Penyakit}

Proses rule didapatkan mengacu dari gejala-gejala yang berhubungan dengan penyakit, terdapatlah beberapa rule untuk pengetahuan mengenai penyakit Kista Ovarium, proses rule tersebut adalah sebagai berikut:

Tabel 3.3. Tabel Rule

\begin{tabular}{|c|c|}
\hline \multirow[t]{2}{*}{ Rule 1} & $\begin{array}{l}\text { IF Adanya ketidakteraturan menstruasi (G001) } \\
\text { AND Nyeri pada perut bagian bawah (G002) } \\
\text { AND Perut berasa penuh (G003) } \\
\text { AND Adanya timbul benjolan pada perut (G004) }\end{array}$ \\
\hline & THEN Kistadenoma Ovarii Serosum $\underline{(\mathbf{P 0 0 1})}$ \\
\hline Rule 2 & $\begin{array}{l}\text { IF Nyeri parah saat menstruasi (G005) } \\
\text { AND Menstruasi datang terlambat (G006) } \\
\text { AND Merasa Tidak sanggup mencerna (G007) } \\
\text { AND Berat badan menurun (G008) }\end{array}$ \\
\hline & THEN Kistadenoma Ovarii Musinosum (P002) \\
\hline Rule 3 & $\begin{array}{l}\text { IF Nyeri perut dapat muncul tiba-tiba (G009) } \\
\text { AND Seringkali merasakan nyeri punggung bagian bawah } \\
\text { (G010) } \\
\text { AND Tubuh merasa lemas (G011) } \\
\text { AND Sering muntah-muntah (G012) } \\
\text { THEN Kista Dermoid (P003) }\end{array}$ \\
\hline Rule 4 & $\begin{array}{l}\text { IF Nyeri pada perut bagian bawah (G002) } \\
\text { AND Nyeri parah saat menstruasi (G005) } \\
\text { AND Nyeri saat berhubungan seksual (G013) } \\
\text { AND Gangguan saat buang air besar/kecil adanya darah pada } \\
\text { urine/tinja (G014) } \\
\text { AND Pendarahan menstruasi berlebihan (G015) } \\
\text { AND Sulit punya anak dalam kurun waktu 1 tahun (G016) } \\
\text { THEN Kista Endometriosis (P004) }\end{array}$ \\
\hline
\end{tabular}

\subsection{Pohon Keputusan}

Setelah mendapatkan gejala penyakit dari data yang telah ada, maka tahap selanjutnya adalah perancangan pohon keputusan yang dapat membantu dalam mengklasifikasikan penyakit berdasarkan gejala-gejala yang diperoleh.

Dengan adanya pohon keputusan setiap penyakit yang mempunyai gejala yang sama maka dapat langsung dihubungkan dengan penyakit yang mempunyai gejala yang sama. Adapun pohon keputusan dari sistem pakar ini dapat digambarkan seperti Gambar 3.1. 


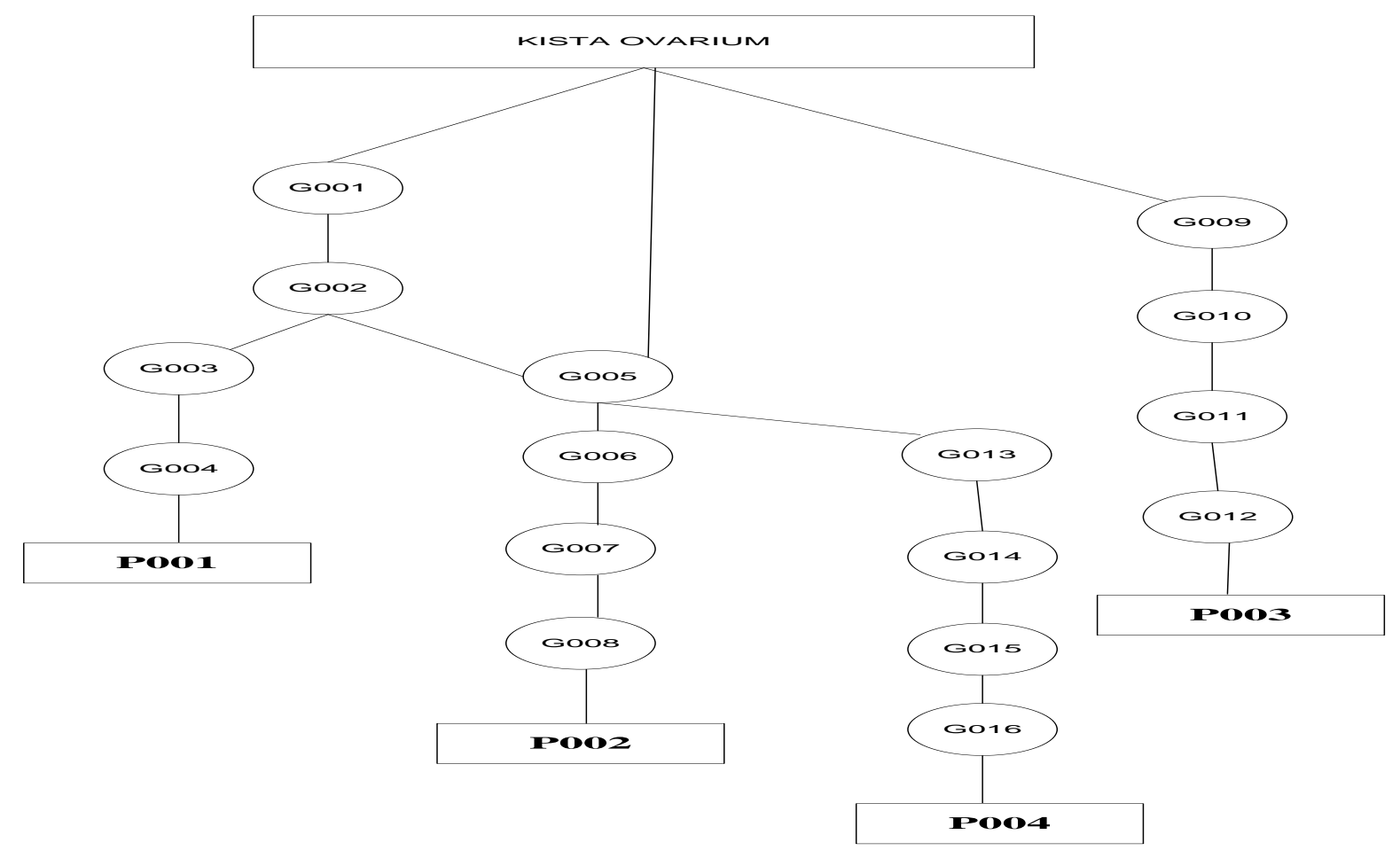

Gambar 3.1. Pohon Keputusan

\section{IMPLEMENTASI DAN PENGUJIAN SISTEM}

\subsection{Halaman Home Sistem}

Halaman ini merupakan halaman awal yang dapat diakses pasien untuk melakukan konsultasi pada sistem. Pada halaman home sistem terdapat beberapa menu antara lain menu informasi, menu konsultasi, menu petunjuk, dan menu kritik dan saran. maka akan muncul halaman seperti pada Gambar 4.1. berikut ini:

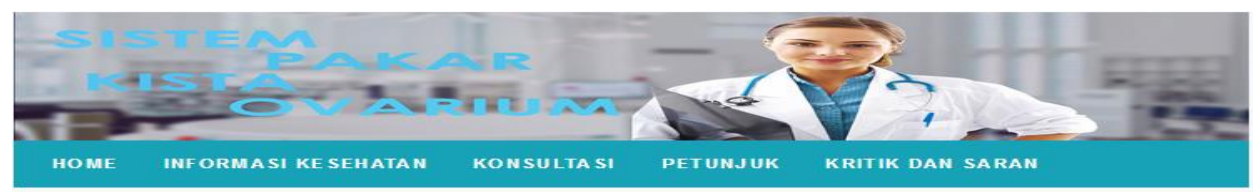

\section{Apa itu Kista Ovarium ????}

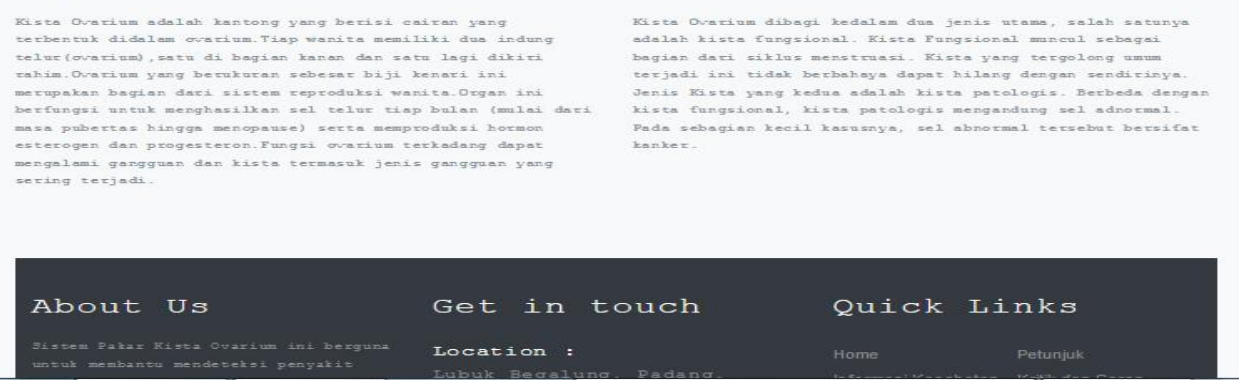

Gambar 4.1. Tampilan Home Sistem 


\subsection{Halaman Daftar Pertanyaan Konsultasi}

Halaman daftar pertanyaan konsultasi ini merupakan halaman yang berisi daftar-daftar pertanyaan gejala yang berhubungan dengan penyakit Kista Ovarium, pertanyaan ini akan muncul setelah pasien telah melakukan registrasi sebelumnya seperti pada Gambar 4.2. berikut ini adalah bentuk beberapa tampilan pertanyaan:

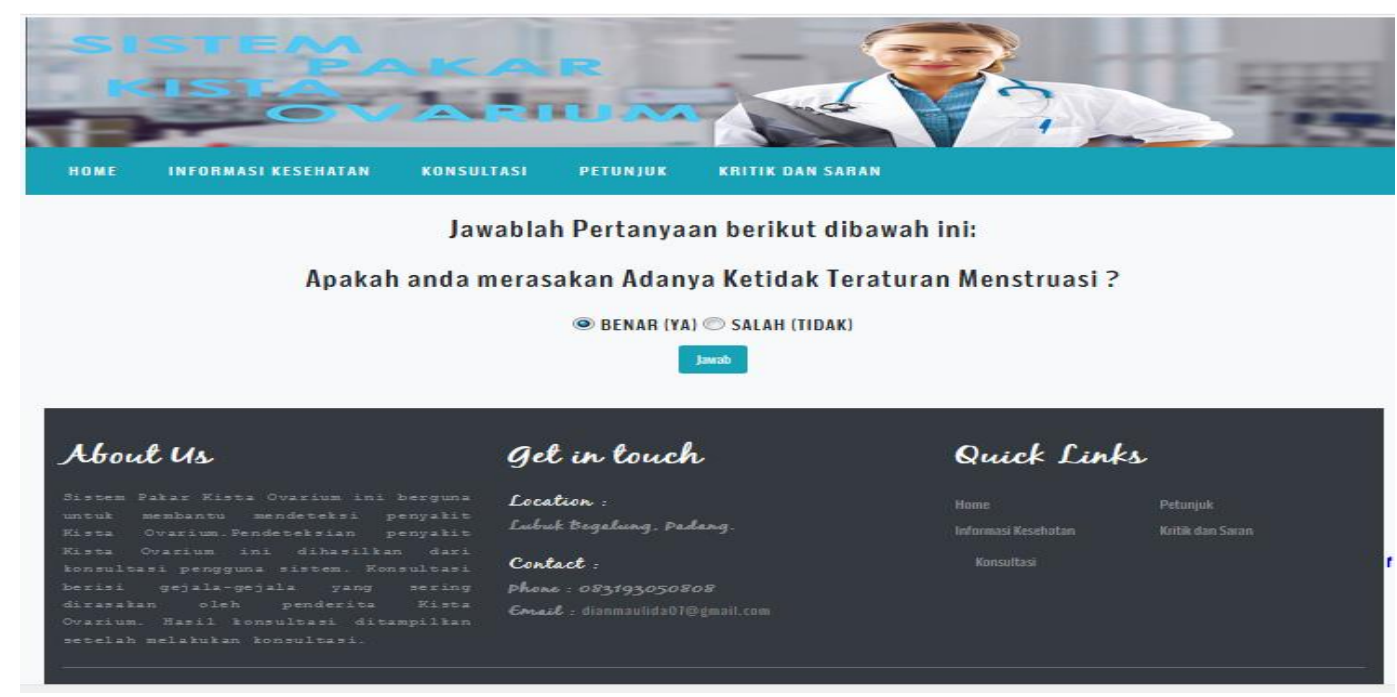

Gambar 4.2. Tampilan Pertanyaan Gejala

\subsection{Halaman Hasil Konsultasi Pasien}

Halaman hasil konsultasi merupakan hasil yang diberikan sistem terhadap konsultasi yang dilakukan oleh user, seperti pada Gambar 4.3. berikut ini:

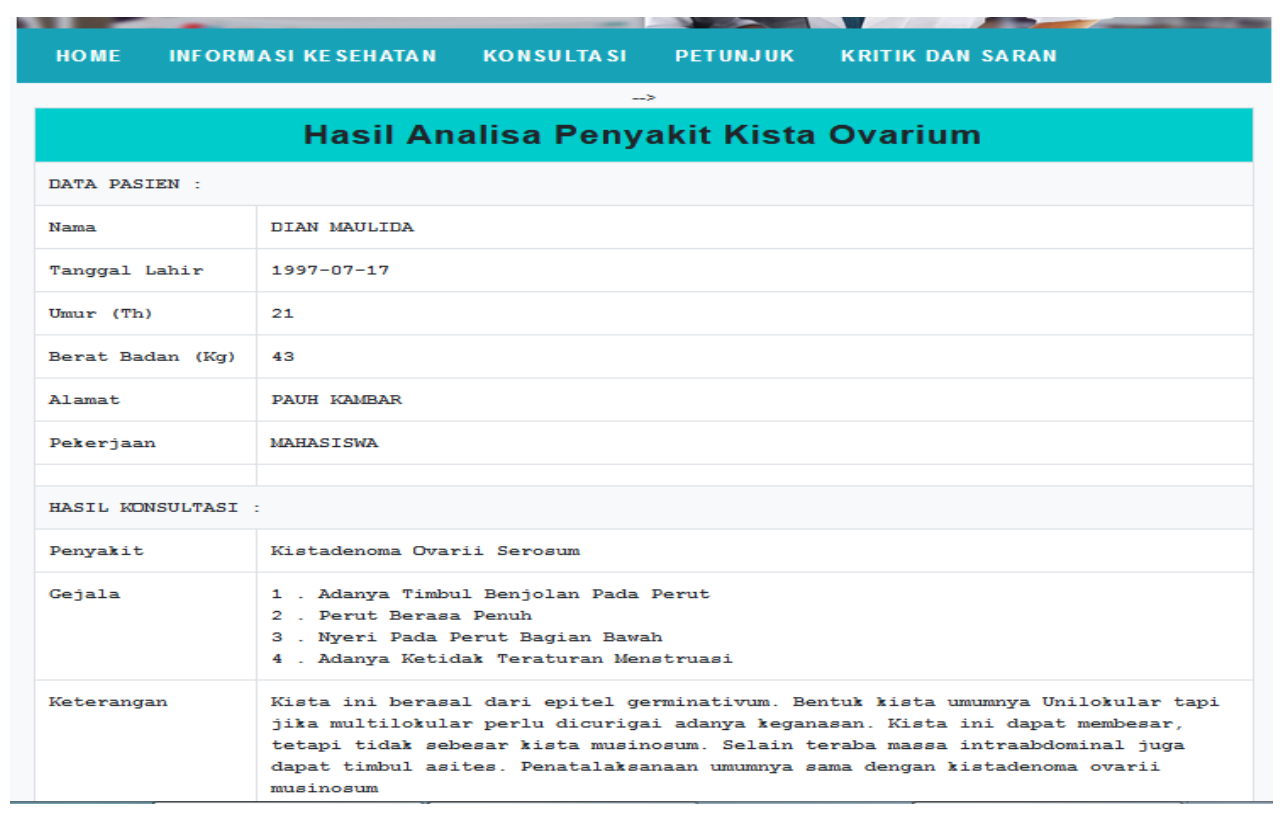

Gambar 4.3 Tampilan Hasil Konsultasi Pasien 


\subsection{Halaman Pengolahan Data Gejala}

Halaman pengolahan data gejala digunakan untuk mengolah data gejala seperti tambah data gejala, edit gejala dan hapus data gejala. Untuk mengakses halaman gejala, admin dapat mengklik menu gejala pada home admin, seperti pada Gambar 4.4 berikut ini

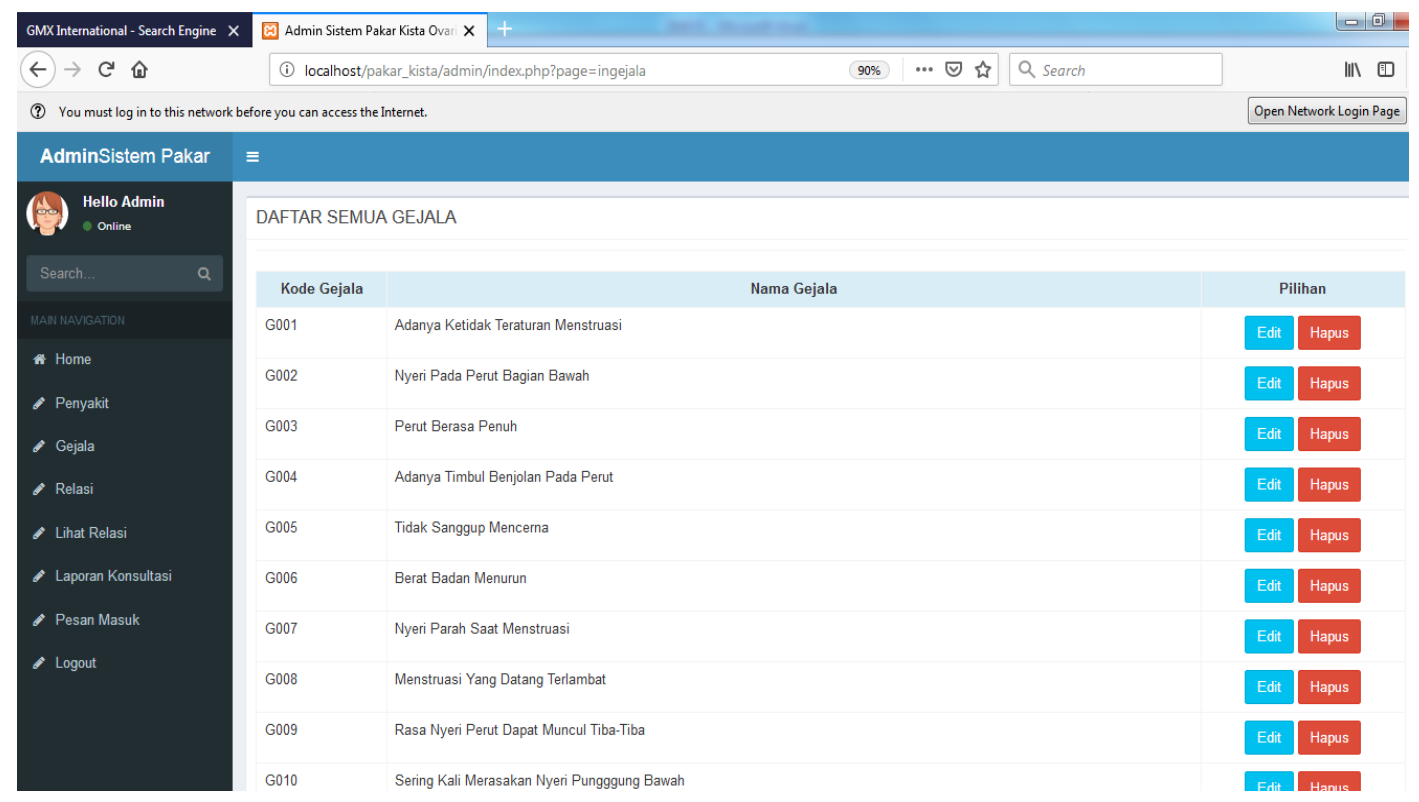

Gambar 4.4 Tampilan Pengolahan Data Gejala

\subsection{Halaman Pengolahan Data Penyakit}

Halaman pengolahan data penyakit digunakan untuk mengolah data penyakit seperti tambah data penyakit, edit penyakit dan hapus data penyakit. Untuk membuka form penyakit, admin dapat mengklik menu penyakit yang tersedia pada home admin, seperti pada Gambar 4.5 berikut ini:

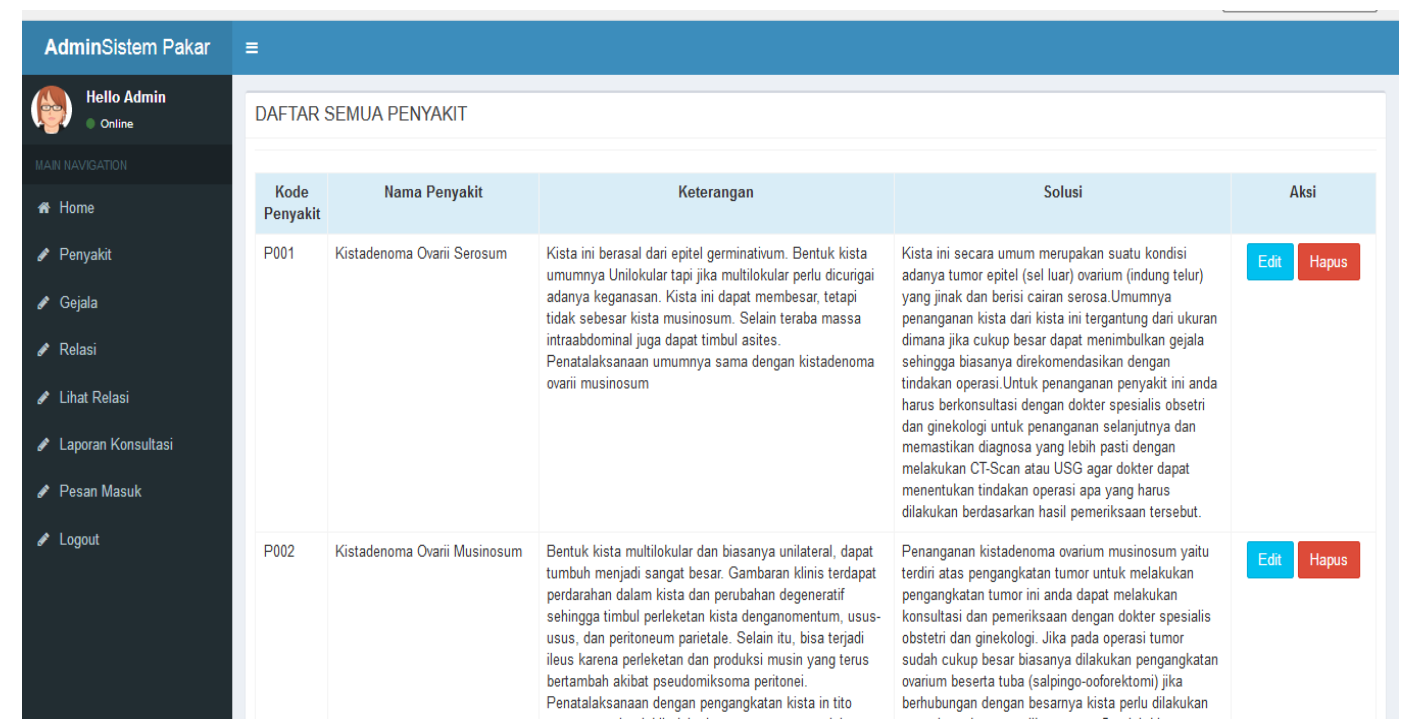

Jurnal KomtekInfo Vol : 6 No : $1 \| 2019$ 
Gambar 4.5 Tampilan Pengolahan Data Penyakit

\subsection{Halaman Pengolahan Data Lihat Relasi}

Halaman yang berisi pengolahan data relasi antara data gejala dengan data penyakit admin dapat mengklik menu lihat relasi pada home admin, seperti pada Gambar 4.6 berikut ini:

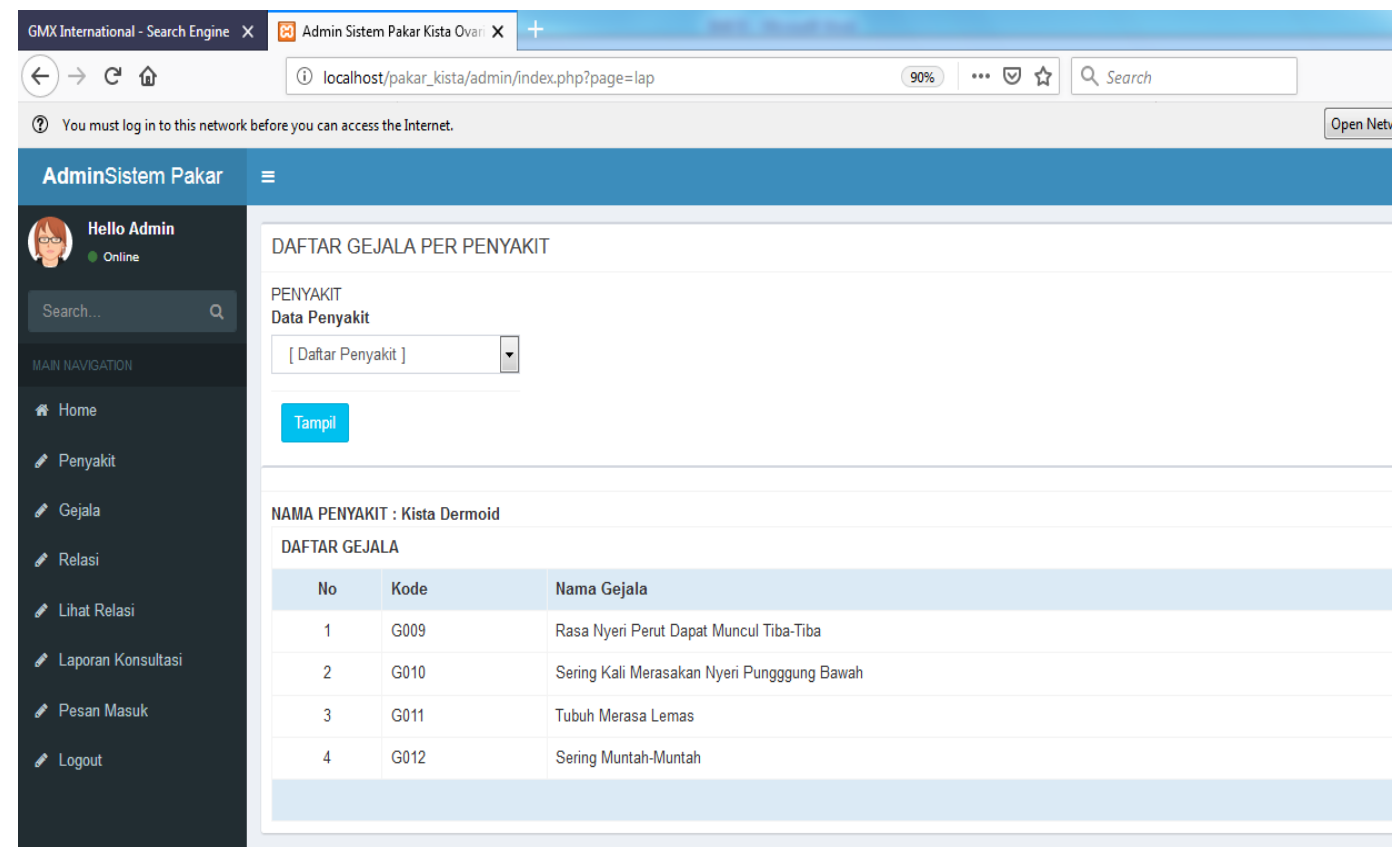

Gambar 4.6 Tampilan Pengolahan Data Lihat Relasi

\section{KESIMPULAN}

Setelah dilakukan analisa proses terhadap penyakit Kista Ovarium maka diperoleh kesimpulan sebagai berikut:

1. Sistem pakar yang dibangun ini dapat membantu user atau pasien dalam mendiagnosa penyakit Kista Ovarium berdasarkan gejala-gejala yang dipilih oleh user atau pasien saat konsultasi.

2. Sistem pakar ini penelusurannya menggunakan metode penalaran Forward Chaining yang bisa digunakan untuk melakukan penelusuran berdasarkan gejala-gejala sehingga dapat menghasilkan solusi pada penyakit Kista Ovarium.

3. Dengan memanfaatkan database MySql, sistem pakar yang dibangun ini mampu menyimpan representasi pengetahuan pakar berdasarkan penalaran bottom-up (Forward Chaining) serta dapat menyimpan data-data konsultasi terdahulu yang dijadikan sebagai tolak ukur untuk konsultasi-konsultasi berikutnya. 


\section{DAFTAR PUStaka}

[1] Gusman, Aggy Pramana. "Sistem Pakar Untuk Mendiagnosa Gangguan Autis Pada Anak Dengan Metode Forward Chaining." PENDIDIKAN TEKNOLOGI INFORMASI UPI-YPTK 2.1 (2017).

[2] Andriani, Anik. 2017. Pemrograman Sistem Pakar. Yogyakarta: MediaKom.

[3] Asmara, Rini, S. Kom, and M. Kom. "SISTEM INFORMASI PENGOLAHAN DATA PENANGGULANGAN BENCANA PADA KANTOR BADAN PENANGGULANGAN BENCANA DAERAH (BPBD) KABUPATEN PADANG PARIAMAN." Jurnal J-Click 3.2 (2017).

[4] Firman, Astria, Hans F. Wowor, and Xaverius Najoan. "Sistem Informasi Perpustakaan Online Berbasis Web." Jurnal Teknik Elektro dan Komputer 5.2 (2016): 29-36.

[5] Swara, Ganda Yoga, and Yunes Pebriadi. "REKAYASA PERANGKAT LUNAK PEMESANAN TIKET BIOSKOP BERBASIS WEB." Jurnal TeknoIf 4.2 (2016).

[6] Putri, Anggia Dasa, and M. Kom. "SISTEM PAKAR MENDETEKSI TINDAK PIDANA CYBERCRIME MENGGUNAKAN METODE FORWARD CHAINING BERBASIS WEB DI KOTA BATAM." Edik Informatika 3.2 (2017): 197-210.

[7] Yudhanto Yudha dan Agus Purbayu. 2014. Toko Online dengan PHP dan MySQL. Jakarta: PT.Elex Media Komputindo.

[8] Tohari,Hamim. 2014.Analisa serta Perancangan Sistem Informasi Melalui Pendekatan UML.Yogyakarta: Penerbit Andi.

[9] A.S Rosa dan M. Shalahuddin. 2014. Rekayasa Perangkat Lunak. Bandung.: Penerbit Informatika.

[10] Sidik, Betha. 2017. Pemrograman Web Dengan Php. Bandung: Informatika Bandung.

[11] Dr.H.A.Rusdiana, M.M dan Moch. Irfan, S.T., M.Kom. 2014. Sistem Informasi Manajemen. Bandung: Pustaka Setia. 